\title{
Penerapan Sistem Kendali XY-Stage dan Modulasi Laser Pada Tomografi Fotoakustik Menggunakan Arduino
}

\author{
Gong Matua*1, Triyogatama Wahyu Widodo ${ }^{2}$, Mitrayana ${ }^{3}$ \\ ${ }^{1}$ Prodi Elektronika dan Instrumentasi, DIKE, FMIPA UGM, Yogyakarta, Indonesia \\ ${ }^{2}$ Departemen Ilmu Komputer dan Elektronika, FMIPA UGM, Yogyakarta, Indonesia \\ ${ }^{3}$ Departemen Fisika, FMIPA UGM, Yogyakarta, Indonesia \\ e-mail: *1' gong.matua2@gmail.com,${ }^{2}$ Triyogatama@ugm.ac.id,$\underline{3 \text { mitrayana@ugm.ac.id }}$
}

\begin{abstract}
Abstrak
Tomografi fotoakustik merupakan suatu sistem pemanfaatan efek fotoakustik yang digunakan untuk mendapatkan citra dengan resolusi dan kontras yang tinggi. Tujuan penelitian adalah membuat rancang bangun mekanik xy-stage dan menerapkan sistem kendali pada modulasi laser. Perancangan sistem terdiri dari perancangan perangkat keras dan lunak. Perancangan perangkat keras meliputi perancangan perangkat optik dan perancangan perangkat elektronika menggunakan mikrokontroler Arduino. Perancangan perangkat lunak menggunakan aplikasi Arduino IDE, Audacity dan Matlab.

Hasil uji perekaman menunjukkan bahwa puncak sinyal fotoakustik pada perekaman dengan adanya sampel lebih tinggi dibandingkan perekaman tanpa sampel. Berdasarkan uji jarak tempuh pergerakan mekanik xy-stage menggunakan motor stepper jenis bipolar Nema 17, diperoleh jarak tempuh $(4,046 \pm 0,005)$ mm untuk gerakan motor satu putaran dan dibutuhkan 25 step untuk memperoleh jarak tempuh sejauh $(0,50 \pm 0,05) \mathrm{mm}$ yang digunakan dalam proses pemayaran. Proses pemayaran telah dapat menampilkan hasil citra yang sesuai dengan area scanning, proses pemayaran dilakukan terhadap objek jaringan lunak berupa pankreas yang mengalami tumor.
\end{abstract}

Kata kunci-Tomografi Fotoakustik, Arduino, Stage-xy, Pemayaran, Motor stepper

\begin{abstract}
Photoacoustic tomography is a system of utilization of the photoacoustic effect is used to obtain image-processing with high resolution and contrast. The purpose of studies is to design a mechanics xy-stage and implement control systems in laser modulation. The system design consists of designing hardware and software. Hardware design includes the design of optical devices and the design of electronic devices using the Arduino microcontroller. Software design using Arduino IDE, Audacity and Matlab.

Recording test results showed that the photoacoustic signal peaks on the recording with the samples was higher than the recording unsampled. Based on the test mileage xy-stage mechanical movement using a type of bipolar stepper motor Nema 17, earned mileage (4.046 \pm $0.005) \mathrm{mm}$ for the motor movement for one revolution and it takes 25 steps to obtain the distance as far $(0.50 \pm 0.05) \mathrm{mm}$ used on scanning process. Image-processing has been able to show the results of the image corresponding to the scanning area, the process is carried out on the object-imaging soft tissues such as the pancreas with cell tumor tissue.
\end{abstract}

Keywords - Photoacoustic Tomography, Arduino, Stage-xy, Image-Processing, Motor stepper 


\section{PENDAHULUAN}

$\mathrm{P}$ ada beberapa tahun terakhir, ilmu pencitraan biomedik telah banyak diterapkan, dan sudah dikembangkan dengan sistem pencitraan terbaru yaitu tomografi fotoakustik. Tomografi fotoakustik merupakan suatu sistem pemanfaatan efek fotoakustik yang digunakan untuk mendapatkan citra dengan resolusi dan kontras yang tinggi. Tomografi fotoakustik pertama kali diterapkan pada otak tikus untuk mendeteksi kanker dini [1]. Tomografi fotoakustik sangat luas pengembangannya, mulai dari rancang bangun alat sampai kepada proses rekontruksi citra. Proses imaging pada sistem tomografi fotoakustik diperoleh berdasarkan pengaruh fotoakustik yang menggabungkan keunggulan hasil optik yang kontras dan resolusi spasial ultrasonik untuk pencitraan [2].

Pada pengembangannya, tomografi fotoakustik digunakan untuk pemantauan tumor angiogenesis, pemetaan darah oksigenasi, pencitraan otak fungsional, dan deteksi kulit melanoma. Bidang-bidang pengolahan citra pada biomedik yang banyak digunakan saat ini adalah pencitraan tomografi fotoakustik. Contohnya adalah Single Photon Emission Computerised Tomography (SPECT), Positron Emission Tomography (PET), Magnetic Resonance Imaging (MRI) dan Electrical Impedance Tomography (EIT), Computerised AxialTomography (CAT) [2].

Dengan memiliki sistem pencitraan terbaru, tomografi fotoakustik menarik minat para peneliti untuk melakukan penelitian. Pemanfaatan efek fotoakustik pada jaringan lunak tentunya menjadi hal yang baru untuk diteliti. Hal ini karena selama ini efek fotoakustik banyak dimanfaatkan untuk menganalisis karakteristik gas, baik itu dalam bidang biologi maupun pertanian [3].

Dalam bidang biomedis, sistem fotoakustik telah digunakan untuk mendeteksi etilen dari emisi kulit dan pernafasan orang sebagai indikator kerusakan kulit akibat penyinaran ultraviolet dan radikal bebas pada peroksidalipid [4]. Kombinasi sistem pencitraan fotoakustik dengan melibatkan pencitraan optik dan ultrasonic mampu menghasilkan gambar resolusi tinggi dengan kedalaman penetrasi yang baik [5]. Visualisasi sel dalam tiga dimensi (3D) telah menjadi salah satu tantangan utama dalam rekayasa jaringan, telah diterapkan mikroskopi fotoakustik dari distribusi spasial dan proliferasi temporal sel dalam perancah porous tiga dimensi dengan ketebalan lebih dari $1 \mathrm{~mm}[6]$.

Sistem pencitraan pada tomografi fotoakustik tentunya memerlukan sebuah platform yang akan digunakan untuk melakukan proses pemayaran terhadap objek. Telah banyak model rancangan yang diterapkan dalam penelitian-penelitian sebelumnya pada tomografi fotoakustik untuk mendukung proses pemayaran. Disamping itu, proses pemanfaatan sinyal akustik juga sudah banyak dilakukan dengan cara yang berbeda, salah satunya adalah dengan pemanfaatan laser dan transduser [7]. Banyaknya komponen pendukung dalam pembuatan alat ini, dapat diketahui bahwa dana yang dikeluarkan tentu juga banyak, sehingga perlu dilakukan suatu perwujudan untuk mengimplementasikan sistem tomografi fotoakustik dengan rangkaian elektronika sederhana tetapi mampu bekerja dengan kualitas yang baik.

Di Laboratoriumatom Inti Jurusan Fisika FMIPA UGM, telah dirancang suatu alat pencitraan fotoakustik berbasis diode laser dengan model sel terbuka [8]. Prototipe sistem ini berhasil memanfaatkan mikrofon komersial yang bekerja pada frekuensi audio. Ditunjukan pula keberhasilan pengolahan data fotoakustik secara software berbasis transformasi fourier, hal ini mengurangi penggunaan perangkat keras dan biaya yang dibutuhkan.

Alat pencitraan fotoakustik yang ada di laboratorium tersebut memiliki mekanik $x y$-stage dengan luas jangkauan pemayaran sebesar $(2,5 \times 2,5) \mathrm{mm}^{2}$ dan sistem modulasi laser masih menggunakan rangkaian elektronika yang rumit. Sehingga perlu dilakukan penyederhanaan alat yang dapat menghasilkan jangkauan pemayaran lebih luas. Penerapan sistem kendali pada rancang bangun alat dalam penelitian ini merupakan bentuk pengembangan dari alat fotoakustik yang terdapat pada Laboratorium Atom Inti Jurusan Fisika FMIPA UGM dengan luas jangkauan lebih besar dan menggunakan rangkaian elektronika sederhana.

IJEIS Vol. 7, No. 2, October $2017: 149-160$ 


\section{METODE PENELITIAN}

\subsection{Analisis}

Sistem pencitraan fotoakustik yang dilakukan oleh [5] sedikit mirip dengan rancang bangun alat yang telah dibuat. Laser yang digunakan adalah sama yaitu jenis laser diode, hanya saja proses pemayaran dilakukan menggunakan bantuan cermin dan lensa sebagai pengatur sudut arah tembakan laser dan pengaturan fokus. Selain itu pendeteksi sinyal akustik juga menggunakan transduser ultrasonik, hal ini masih tergolong cukup mahal dari segi biaya. Pada rancang bangun alat yang akan dibuat dalam penelitian ini, diterapkan sistem mekanik dua dimensi $x y$-stage untuk proses pemayaran. Mekanik xy-stage digerakkan menggunakan motor stepper jenis bipolar. Untuk proses pendeteksian sinyal akustik, digunakan mikrofon jenis electret condenser yang ada di pasaran sebagai detektor. Dari segi biaya, rancang bangun alat pada penelitian ini tergolong murah, sehingga tidak menjadi masalah dalam sistem pengembangan dan portabilitas di lapangan.

Penerapan sistem perangkat tomografi fotoakustik terdiri dari dua bagian utama, yaitu bagian hardware meliputi peralatan optik dan rangkaian elektronika, serta bagian software sebagai processing dan apliksi interface. Peralatan fotoakustik terdiri dari susunan perangkat optik yang berfungsi untuk menghasilkan suatu gelombang bunyi yang selanjutnya akan direkam oleh mikrofon, sehingga didapat suatu parameter fisis dari objek yang menggambarkan sumber informasi dari objek tersebut. Rangkaian elektronik dirangkai untuk mendukung sistem peralatan berjalan secara otomatis, yaitu membuat suatu sistem kendali laser dan kendali motor yang bekerja secara otomatis menggunakan software pada komputer. Bagian software bertujuan untuk membantu kerja dari hardware (perangkat alat fotoakustik dan rangkaian elektronika) agar berjalan dengan baik serta dapat dianalisis untuk proses identifikasi.

Berdasarkan hasil analisis diatas maka dapat disimpulkan pengembangan pada luas pemayaran dapat dilakukan dengan membuat sistem mekanik $x y$-stage yang lebih besar. Sistem modulasi laser dirancang dengan rangkaian elektronika sederhana dan perekaman sinyal fotoakustik menggunakan electret condenser microphone. Dari segi biaya, semua sistem perancangan dapat tergolong dalam kategori dana yang minimalis. Dari hasil penelitian sebelumnya dianggap perlu dilakukan pengembangan, maka pada penelitian ini dilakukan rancangan mekanik xy-stage dan modulasi laser yang dijelaskan pada sub bab rancangan sistem.

\section{$2.2 \quad$ Perancangan Sistem}

\section{2.1 Perancangan Sistem Modulasi Laser}

Modulasi cahaya adalah teknik modulasi yang menggunakan berkas cahaya berupa pulsa

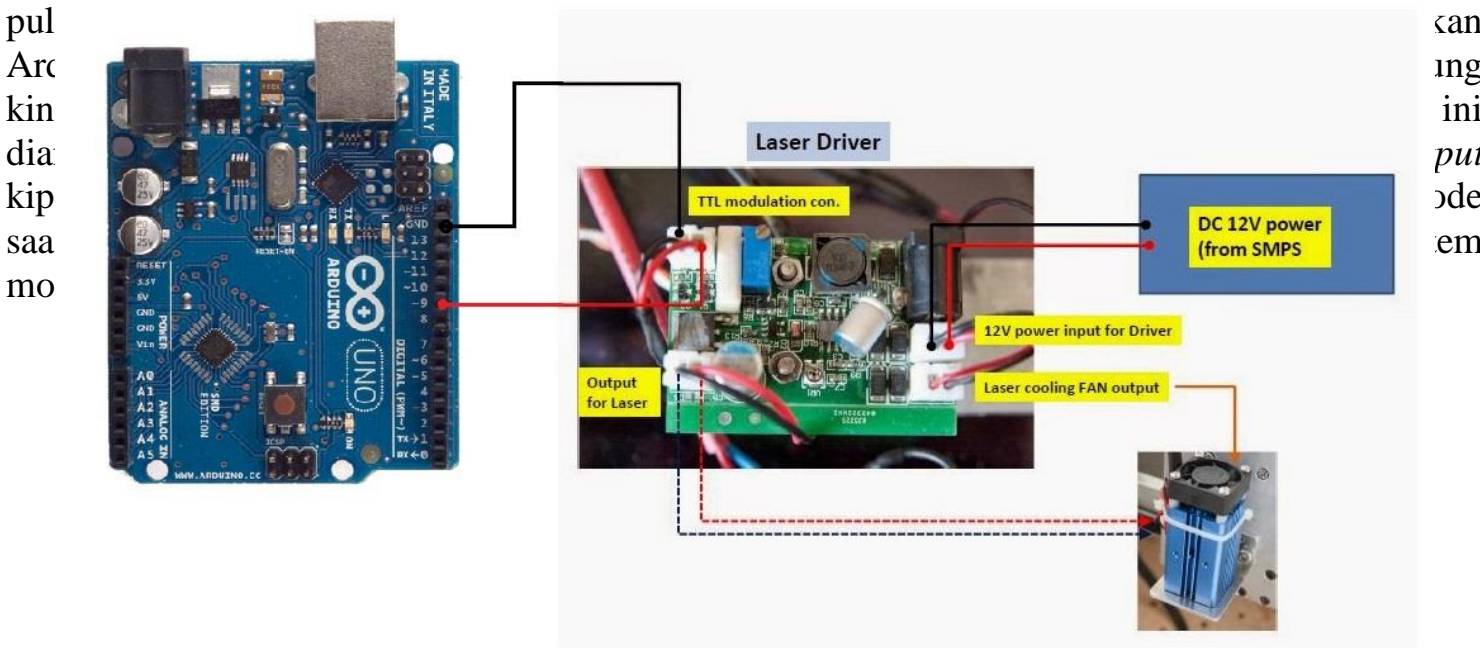

Gambar 1 Rancangan Unit Proses Modulasi Laser 
Pada sistem modulasi ini terdiri dari dua bagian yaitu laser dan audio detector berupa mikrofon. Laser dimodulasi dengan amplitudo dan duty cycle tertentu, selanjutnya akan ditembakkan ke objek untuk menimbulkan suatu gelombang bunyi, gelombang bunyi tersebut yang selanjutkan akan direkam oleh mikrofon untuk mendeteksi puncak sinyal akustik. Modulasi adalah suatu proses penumpangan sinyal-sinyal informasi ke dalam sinyal pembawa (carrier), sehingga dapat ditransmisikan ke tujuan.

\section{2. 2 Perancangan Sistem Perekaman}

Perancangan pada bagian ini dibuat untuk merekam gelombang suara yang dihasilkan oleh objek akibat tembakan laser yang termodulasi, dimana hasilnya dapat langsung ditampilkan di komputer setelah proses perekaman berkahir. Proses perekaman menggunakan software Audacity 2.0.4, menghasilkan filedata rekaman dalam bentuk WAV. Jenis mikrofon yang digunakan dalam penelitian ini merupakan jenis mikrofon yang prinsip kerjanya kapasitor. Sehingga membutuhkan suatu komponen tambahan berupa soundcard untuk memberikan beda potensial pada mikrofon. Mikrofon diletakkan tepat menghadap ke arah tembakan laser dan sangat dekat dengan objek, hal ini bertujuan untuk mendapatkan sinyal gelombang suara yang lebih baik. Berikut adalah skema rangcangan sistem perekaman ditunjukkan pada Gambar 2.

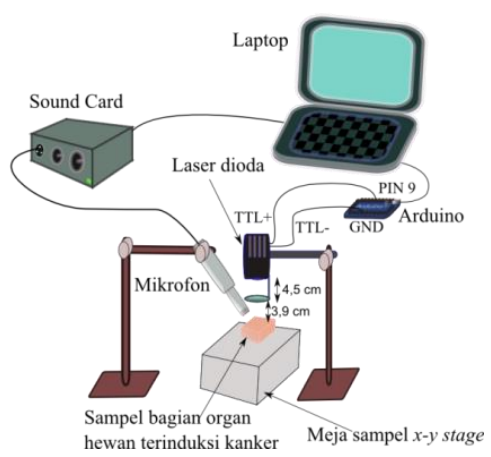

Gambar 2 Rancangan sistem perekaman

Cara kerjanya yaitu pada saat laser ditembakkan ke objek, maka akan terjadi suatu ekspansi memuai dan menyusut pada objek. Dari situlah yang kemudian muncul suatu gelombang bunyi yang dapat direkam oleh mikrofon. Mikrofon akan merekam sinyal suara dari proses vibrasimolekul pada objek akibat tembakan laser yang termodulasi dan sinyal tersebut langsung dikirimkan ke software untuk selanjutnya akan diolah sehingga dapat melihat puncak akustiknya. Jenis mikrofon yang digunaka pada percobaan ini mampu mendeteksi sinyal suara sampai dengan $20 \mathrm{KHz}$, yaitu jenis electret condenser microphone.

\section{2.3 Perancangan Perangkat Mekanik XY-Stage}

Mekanik xy-stage digerakkan oleh motor stepper untuk menghasilkan deret fourier yang dapat ditransformasikan sehingga dapat diketahui model bentuk citranya. Berikut susunan rancangan perangkat eletronika untuk motor penggerak $x y$-stage seperti pada Gambar 3.

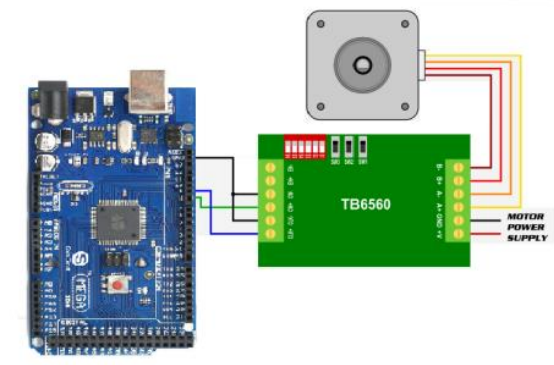

Gambar 3 Rancangan sistem motor stepper

IJEIS Vol. 7, No. 2, October $2017: 149-160$ 
Prinsip kerja pada bagian perangkat elektronika ini adalah komputerakan memberikan program perintah pada arduino sebagai penggerak stage- $x$ dan stage-y untuk memulai proses pemayaran. Proses pemayaran pada objek dilakukan dengan memvariasi resolusi piksel yang diinginkan sesuai dengan ukuran dari objek. Selanjutnya penggerak akan menggeser objek ke seluruh titik pengamatan, sementara itu komputer akan melakukan perekaman akustik melalui mikrofon. Hal ini terus berjalan sampai titik akhir pengamatan. Setelah mencapai posisi akhir maka penggerak akan kembali ke titik posisi awal pengambilan data, data rekaman kemudian diolah untuk menampilkan citra objek secara fotoakustik. Gambar 4 adalah skema rancangan salah satu stage.

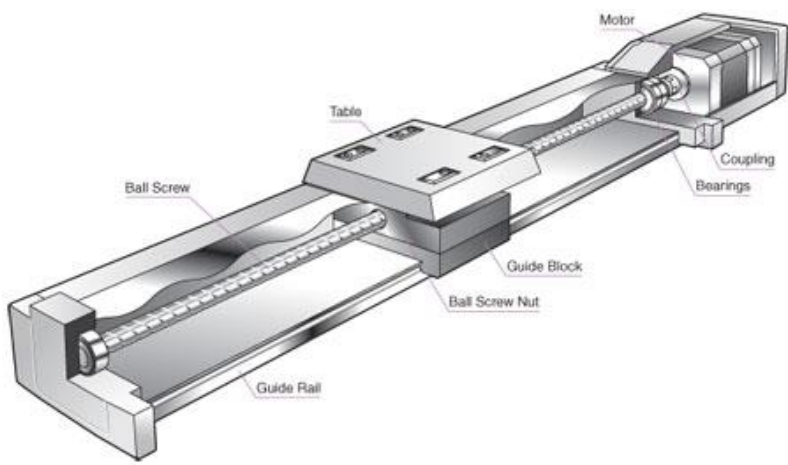

Gambar 4 Skema rancangan salah satu stage

\subsection{Implementasi Perangkat Keras}

\section{3.1 Implementasi Unit Proses Modulasi Laser}

Sistem modulasi laser terdiri dari laser sebagai pemancar cahaya, driver untuk mendukung kinerja laser dan adaptor $12 \mathrm{~V}$ sebagai sumber tegangan eksternal.Semua komponen tersebut didesain untuk dikendalikan oleh mikrokontroler Arduino Uno.Laser menggunakan kabel TTL+ yang ditancapkan pada pin 9 dan kabel TTL- yang ditancapkan pada pin ground. Penggunaan pin TTL pada laser adalah untuk proses modulasi amplitudo sehingga frekuensi pada laser dapat ditentukan. Pada Gambar 5 ditunjukkan susunan rangkaian unit proses perangkat laser.

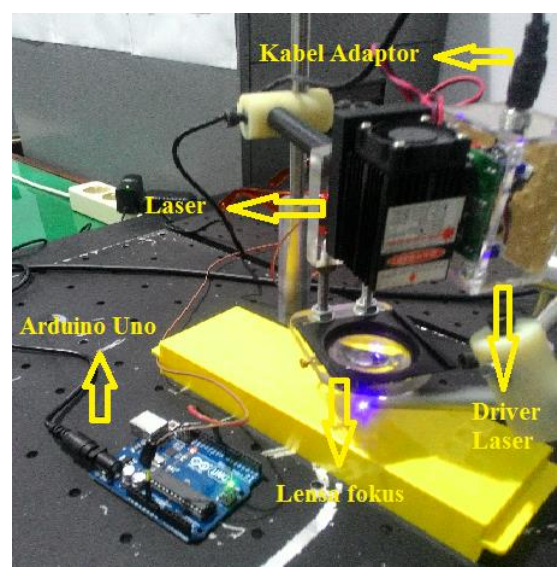

Gambar 5 Implementasi Unit Proses Modulasi Laser

\section{3.2 Implementasi Perancangan Unit Perekaman}

Jenis mikrofon yang digunakan pada penelitian adalah Electrect condenser microphone dengan type Behringer ECM8000. Selain mebutuhkan tambahan eksternal power supply, mikrofon jenis ini juga memerlukan elektronika pendukung berupa soundacrd dengan tipe yang sesuai dengan jenis mikrofonnya untuk dapat merekam gelombang suara yaitu Soundcard Behringer UMC 202HD. Soundacrd ini menjadi perantara penghubung antara mikrofon dan 
komputer, mikrofon ditancapkan pada soundacrd dan kabel USB soundacrd ditancapkan pada USB komputer. Perancangan unit mikrofon seperti yang ditunjukkan pada Gambar 6.

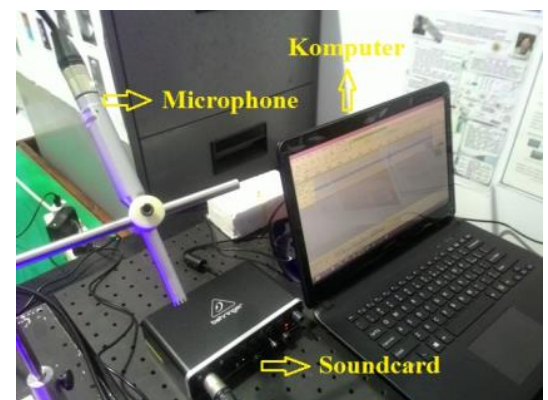

Gambar 6 Implementasi unit proses mikrofon

\section{3.3 Implementasi Unit Mekanik XY-Stage}

Sistem mekanik $x y$-stage digunakan sebagai perangkat yang akan dikendalikan untuk melakukan proses pemayaran, terdiri dari beberapa komponen elektronika seperti power supply, motor stepper, motor driver dan komponen-komponen pendukung lainnya. Xy-stage dijalankan oleh dua motor stepper dengan komunikasi serial yang terhubung pada Arduino Mega2560 dan diprogram oleh software aplikasi MATLAB. Gambar 7 menunjukkan rangkaian pada mikrokontroler Arduino Mega2560 yang akan diprogram untuk sistem mekanik xy-stage.

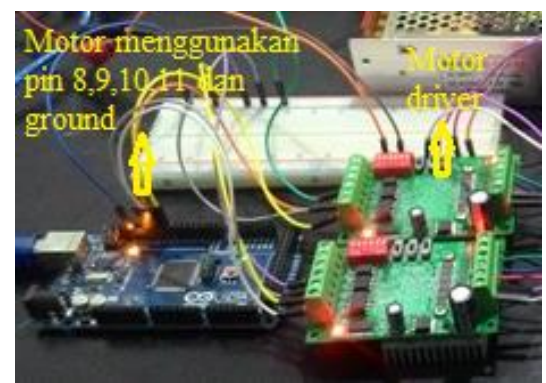

Gambar 7 Implementasi unit proses Arduino Mega2560

Motor stepper yang digunakan adalah motor stepper Nema 17 dua phase dengan step angel $1.8^{\circ}$ membutuhkan tegangan $12 \mathrm{~V}$ dan arus 1.7 A. Motor stepper Nema 17 membutuhkan power eksternal tambahan, hal ini dikarenakan pada board arduino hanya menyediakan tegangan sebesar $5 \mathrm{~V}$ sehingga tidak dapat mendukung kinerja motor. Selain itu untuk dapat menjalankan proses pemayaran, dibutuhkan driver untuk dapat mengatur kecepatan dan arah putar motor stepper. Driver motor yang digunakan pada penelitian ini adalah TB6560 3A single axis, driver ini bekerja pada tegangan (10-35) V sehingga cocok dengan jenis motor stepper yang digunakan pada penelitian ini. Susunan rangkaian motor stpper dan motor driver seperti pada Gambar 8.

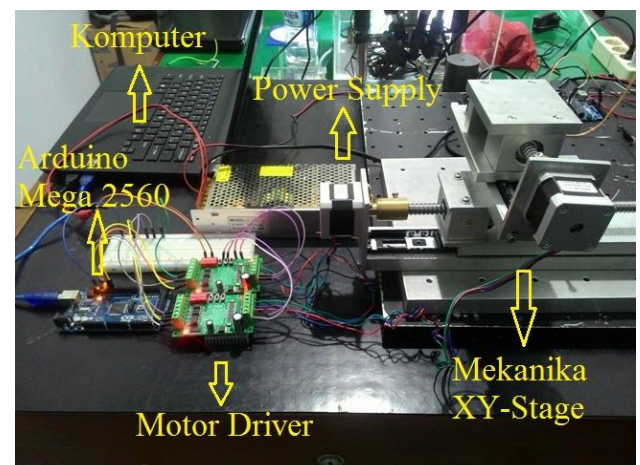

Gambar 8 Implementasi rancangan mekanik $x y$-Stage

IJEIS Vol. 7, No. 2, October 2017 : 149 - 160 
Pada Gambar 9 merupakan skematik susunan kabel pada motor stepper yang dihubungkan ke motor driver. Sebelum melakukan hal tersebut, terlebih dahulu harus diketahui jenis kabel $\mathrm{A}+, \mathrm{B}+, \mathrm{A}-$, dan $\mathrm{B}-$ dari motor, pengecekan dapat dilakukan dengan menggunakan multimeter.

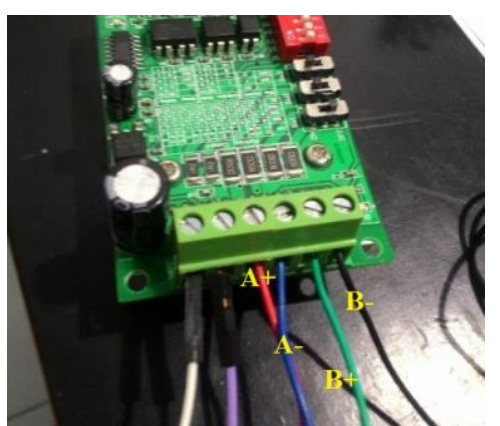

Gambar 9 Susunan pengkabelan motor stepper pada motor driver

\subsection{Implementasi Perangkat Lunak}

Perangkat lunak yang dibuat terbagi menjadi tiga bagian yaitu implementasi program modulasi laser pada mikrokontroler, Implementasi antarmuka proses perekaman, dan yang terakhir adalah Implementasi antar muka proses rekaman pada mikrofon yang digabungkan dengan program penggerak xy-stage. Arduino menggunakan Integrated Development Environment (IDE) yang telah tersedia untuk Arduino, IDE ini menggunakan bahasa modifikasi dari C++ yang dikembangkan khusus untuk Arduino. Perangkat lunak untuk proses perekaman menggunakan software aplikasi audacity untuk merekam gelombang bunyi sekaligus menampilkan spectrum yang didapat.

Perangkat lunak untuk antar muka proses rekaman pada mikrofon yang digabungkan dengan program penggerak xy-stage menggunakan software aplikasi Matlab. Matlab adalah sebuah bahasa dengan kinerja tinggi untuk komputasi masalah teknik. Matlab mengintegrasikan komputasi, visualisasi, dan pemrograman dalam suatu model yang sangat mudah untuk dipakai dimana masalah-masalah dan penyelesaiannya diekspresikan dalam notasi matematika yang familiar.

\section{HASIL DAN PEMBAHASAN}

\subsection{Pengujian Proses Rekaman Puncak Sinyal Akustik}

Pengujian ini untuk mengetahui proses pembacaan puncak sinyal akustik dengan 3 objek berbeda yaitu pengujian terhadap latar, laser dan sampel. Pengujian terhadap latar adalah pengujian rekaman tanpa adanya laser dan sampel, pengujian terhadap laser adalah pengujian rekaman pada laser tanpa adanya sampel dan yang terakhir adalah rekaman terhadap sampel,yaitu proses rekaman pada sampel yang ditembakkan laser. Dari pengujian ini didapat puncak sinyal akustiknya masing-masing yang akan digunakan sebagai perbandingan.

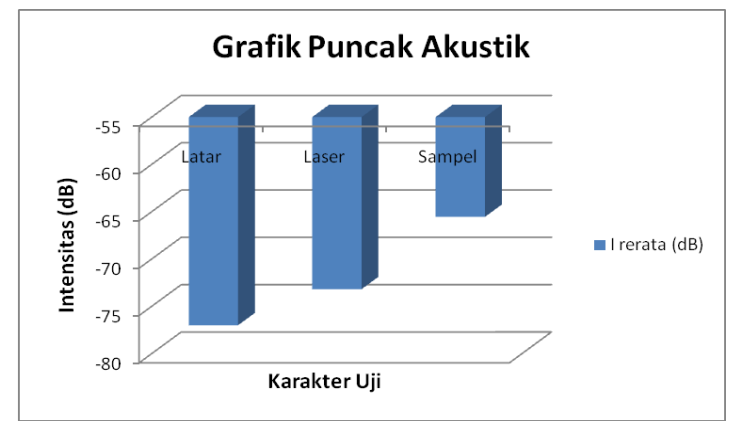

Gambar 10 Perbandingan hasil baca puncak akustik rekaman 
Dari pengujian ini terlihat jelas perbedaan rata-rata puncak akustik tiap karakter yang diuji seperti pada Gambar 10. Grafik menunjukan adanya selisih antara masing-masingobjek yang dijadikan sebagai karakter uji. Hal ini sesuai dengan target pengujian yang sudah dibuat yaitu untuk membuktikan puncak akustik hanya terlihat pada proses pengujian sampel dan laser sedangkan pada latar tidak terlihat. Gambar 11 menunjukkan puncak sinyal fotoakustik pada frekuensi $\pm 18.000 \mathrm{~Hz}$.

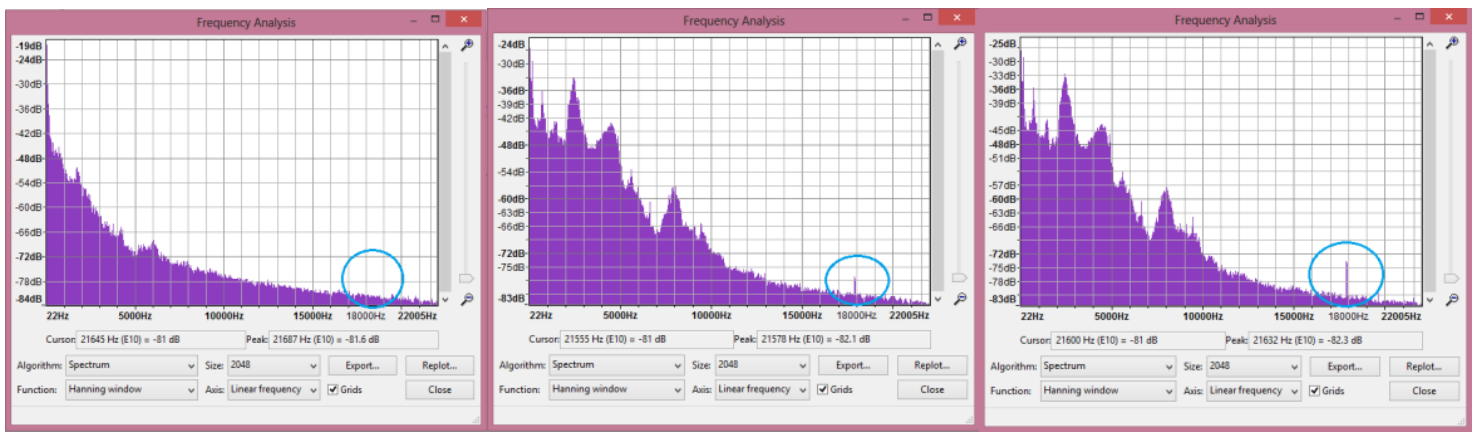

Gambar 11 Hasil perekaman pada latar, laser dan sampel

Untuk pengujian pada laser, walaupun terdapat puncak akustik, namun tidak berada pada puncak yang sama atau lebih tinggi dari puncak pengujian terhadap sampel. Puncak yang didapat dari pengujian terhadap laser merupakan hasil rekaman terhadap tempat sampel dan juga laser itu sendiri. Mikrofon akan tetap merekam aktivitas vibrasi molekul yang terjadi pada tempat sampel, hanya saja puncak akustik yang didapat tidak terlalu tinggi. Hal ini karena laser sudah dimodulasi pada amplitudo dan duty cycle yang disesuaikan dengan sampel uji, sehingga puncak tertinggi akan didapat ketika laser ditembakkan pada saat ada sampel dan tidak dipengaruhi oleh objek selain sampel tersebut

\subsection{Pengujian Jarak Gerak Motor Menggunakan Ball Screw}

Sistem kendali pada penggerak mekanik xy-stage menggunakan motor stepper, sehingga perlu diketahui akurasi sistem kendali yang bekerja pada gerakan satu putaran yang pergerakannya diaktuasikan oleh ball screw. Penentuan nilai jarak gerakansatu kali putaran motor dilakukan dengan cara membuat program penggerak motor stepper sebanyak 200 step. Percobaan ini dilakukan dengan dua arah berbeda sebagai pembanding akurasi gerakan ke arah kanan dan ke kiri.

Proses pengujian ini dilakukan dengan menggunakan dial micrometer, dial micrometer merupakan alat ukur jarak sampai pada skala micrometer. Akan tetapi masih terdapat banyak kekurangan karena proses pemasangan posisi dial micrometer yang rentan terhadap goyangan bahkan getaran dan proses pembacaan pengukuran yang masih dilakukan secara manual. Percobaan ini dilakukan dengan mempertimbangkan kestabilan sistem yang bekerja pada proses pemayaran. Dimana proses pemayaran adalah suatu pergerakan dengan gerakan empat arah berbeda yaitu ke kanan, ke kiri, ke depan dan ke belakang. Pada praktiknya, titik awal proses pemayaran diharapkan menjadi titik kembali setelah menyelesaikan seluruh proses pemayaran, sehingga dibutuhkan pergerakan yang memiliki tingkat presisi tinggi. Pada Table 1 ditunjukkan nilai jarak tempuh motor stepper per satu putaran menggunakan ball screw.

Tabel 1 Nilai rata-rata jarak tempuh satu putaran

\begin{tabular}{|c|c|c|}
\hline Arah Gerakan & $\mathrm{d}$ rerata $(\mathrm{mm})$ & $\Delta \mathrm{d}(\mathrm{mm})$ \\
\hline Pergerakan Ke kanan & 4,01 & 0,01 \\
\hline Pergerakan Ke Kiri & 4,000 & 0,008 \\
\hline
\end{tabular}

IJEIS Vol. 7, No. 2, October 2017 : $149-160$ 
Dari data tersebut diambil salah satu data percobaan yang memiliki ralat paling kecil yaitu pergerakan ke kiri, dimana didapatkan jumlah jarak tempuh motor per satu putaran adalah $(4,000 \pm 0,008) \mathrm{mm}$. Sehingga didapatkan jarak tempuh motor stepper per step adalah $0,02 \mathrm{~mm}$, nilai ini menjadi suatu standarisasi untuk menentukan jumlah step yang diinginkan pada suatu jarak tempuh tertentu. Hal ini sangat berguna untuk menentukan jumlah titik pada proses pemayaran.

Titik fokus laser yang sangat kecil menuntut akurasi yang tinggi untuk gerakan tiap step. Ball screw memenuhi standard tersebut, dimana ball screw sering digunakan pada mesin CNC yang harus memiliki tingkat akurasi hingga ketelitian seperseribu millimeter, ketelitian ini didapat karena terdapat bola-bola kecil pada setiap poros transportier-nya. Ballscrew bekerja seperti lager yang tidak memiliki kelonggaran/spelling namun dapat bergerak dengan lancar. Hal ini yang menjadi dasar pemilihan ball screw sebagai actuator karena penelitian ini sangat beresiko terhadap nilai error skala kecil sampai pada seperseratus millimeter. Dari pengujian ini telah dibuktikan bahwa tingkat akurasi yang diberikan oleh ball screw sudah layak digunakan dalam proses pemayaran. Pergeseran tiap titiknya sebagai objek tembakan laser akan memberikan hasil data scanning yang bagus pada tiap piksel penampil citra.

\subsection{Pengujian Tingkat Presisi Jarak Tempuh Pergeseran Titik}

Pada penelitian ini pergerakan satu titik yang diinginkan pada proses pemayaran adalah sejauh 0,5 mm. Didapatkan jarak tempuh dari pergerakan satu putaran motor adalah $4 \mathrm{~mm}$, seharusnya dapat dijadikan acuan untuk memperoleh jarak tempuh $0,5 \mathrm{~mm}$ dengan nilai jumlah step sebanyak 25 step. Didapatkan dari hasil bagi $4 \mathrm{~mm}$ dibagi jumlah step satu putaran yaitu 200 step, maka didapatkan angka $0,02 \mathrm{~mm}$ per satu step sehingga dibutuhkan 25 step untuk memenuhi jarak tempuh 0,5 mm. Didapatkan dari hasil kali $0,02 \mathrm{~mm}$ dikali 25 jumlah step. Akan tetapi, perlu dilakukan proses kalibrasi untuk mendukung sistem yang diterapkan pada alat yang dibuat. Dengan melakukan kalibrasi, bisa diketahui seberapa jauh perbedaan (penyimpangan) antara harga benar dengan harga yang ditunjukkan oleh alat ukur. Pengujian ini dilakukan untuk mengetahui tingkat akurasi yang diberikan ball screw terhadap pergeseran titik pada proses pemayaran. Pengujian ini akan mendapatkan nilai tetap jumlah step pada satu kali perpindahan titik scanning. Gambar 12 menunjukkan grafik kalibrasi yang telah didapat.

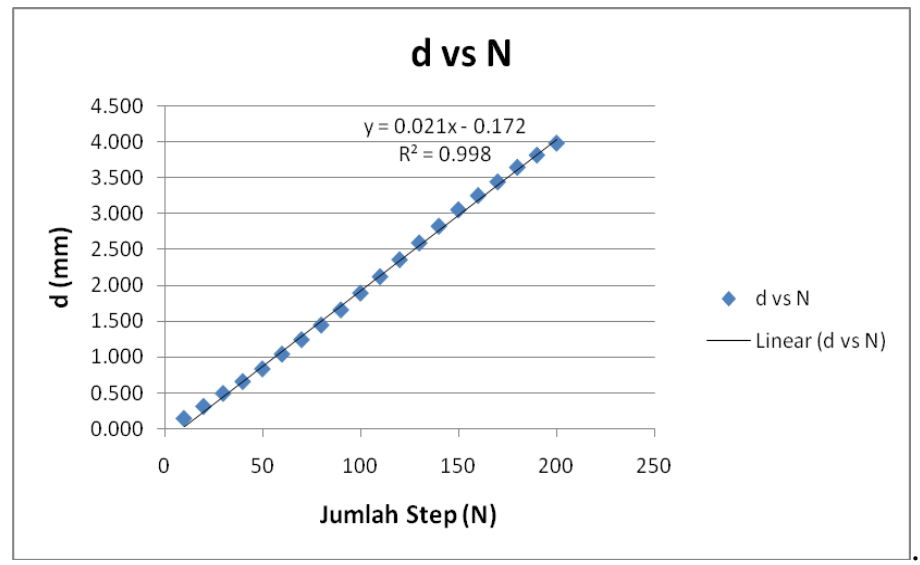

Gambar 12 Grafik kalibrasi jarak tempuh pergeseran titik

Pada Gambar 12 menunjukkan grafik jarak tempuh pergerakan motor terhadap variasi jumlah step yang diberikan. Berdasarkan grafik tersebut hasil pengujian kalibrasi yang didapat sudah mendekati linier, terlihat dari koefisien determinasi yang mendekati angka $1\left(\mathrm{R}^{2}=\right.$ 0,9983). Kemudian nilai jumlah step yang paling mendekati untuk pergerakan $0,5 \mathrm{~mm}$ berada diantara 20 step sampai 30 step dimana didapat nilai rata-rata dari 5 kali percobaan masingmasing $0,371 \mathrm{~mm}$ dan $0,552 \mathrm{~mm}$. Oleh karena itu, grafik kalibrasi diatas dapat mendukung 
penjelasan secara teoritis yang sudah dijelaskan sebelumnya. Maka jumlah step yang dibutuhkan untuk pergerakan $0.5 \mathrm{~mm}$ adalah 25 step, Tabel 2 menunjukkan data hasil pengukuran jarak motor menggunakan actuator ball screw dengan satu kali pergerakan sebanyak 25 step.

Tabel 2 Data hasi pengukuran jarak tempuh 25 step

\begin{tabular}{|c|c|}
\hline $\mathrm{N}=25$ & $\mathrm{~d}(\mathrm{~mm})$ \\
\hline percobaan ke-1 & 0,5 \\
\hline percobaan ke-2 & 0,55 \\
\hline percobaan ke-3 & 0,59 \\
\hline percobaan ke-4 & 0,54 \\
\hline percobaan ke-5 & 0,46 \\
\hline percobaan ke-6 & 0,45 \\
\hline percobaan ke-7 & 0,43 \\
\hline percobaan ke-8 & 0,47 \\
\hline percobaan ke-9 & 0,5 \\
\hline percobaan ke-10 & 0,54 \\
\hline d rerata $(\mathrm{mm})$ & 0,50 \\
\hline$\Delta \mathrm{d}(\mathrm{mm})$ & 0,05 \\
\hline
\end{tabular}

Pada Tabel 2 terlihat bahwa pergerakan motor stepper dengan jumlah 25 step sangat mendekati jarak tempuh $0,5 \mathrm{~mm}$. Dari hasil percobaan ini didapatkan nilai rata-rata pergerakan 25 step adalah $(0,50 \pm 0,05) \mathrm{mm}$. Berdasarkan percobaan ini didapatkan nilai standard untuk pergeseren satu titik yang akan dilakukan pada proses pemayaran adalah 25 step.

\subsection{Pengujian Proses Pemayaran Menggunakan Mekanik XY-Stage}

Berdasarkan pemaparan yang sudah dijelaskan tentang pengujian motor sebagai penggerak mekanik xy-stage, maka pada bagian ini akan diterapkan nilai ukur yang sudah didapat untuk menjalankan proses pemayaran. Proses pemayaran ini adalah tujuan akhir dari pembuatan alat, yaitu mendapatkan suatu citra dari objek yang diteliti. Pada bagian ini akan ditampilkan citra beberapa hasil proses pemayaran sebagai bukti bahwa sistem yang dibuat sudah memenuhi tujuan awal dari penelitian yaitu membuat suatu rancang bangun alat tomografi fotoakustik.

Proses pemayaran yang pertama dilakukan pada objek jaringan lunak berupa pankreas yang sudah mengalami tumor secara merata. Gambar 13 merupakan tampilan objek dan hasil citra yang sudah didapat dari proses pemayaran seluas $\left(\begin{array}{lll}1 & \mathrm{x} & 1\end{array}\right) \mathrm{cm}^{2}$, dimana dibutuhkan pergerakan sebanyak 20 kali.

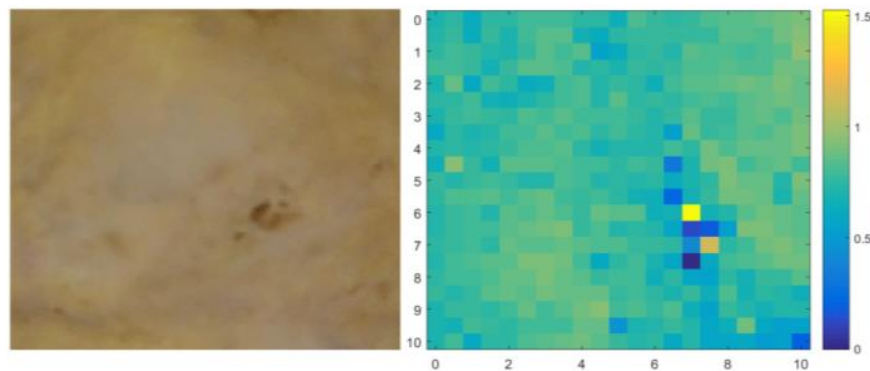

Gambar 13 Hasil citra pada jaringan tumor 
Pada Gambar 13 terlihat bahwa hasil citra seragam, hanya terdapat beberpata noise akibat dari beberapa permukaan yang tidak rata. Hal ini membuktikan bahwa proses pemayaran sudah sepenuhnya berjalan dengan baik. Untuk mendapatkan perbedaan yang lebih menonjol maka perlu diberikan suatu perbedaan pada sampel agar dapat menampilkan hasil citra yang lebih variatif. Gambar 14 adalah tampilan hasil citra dari suatu jaringan tumor yang sudah ditambahkan beberapa material padat berupa kawat besi pada permukaannya. Sama seperti proses pemayaran sebelumnya, luas proses pemayaran adalah $(1 \times 1) \mathrm{cm}^{2}$.

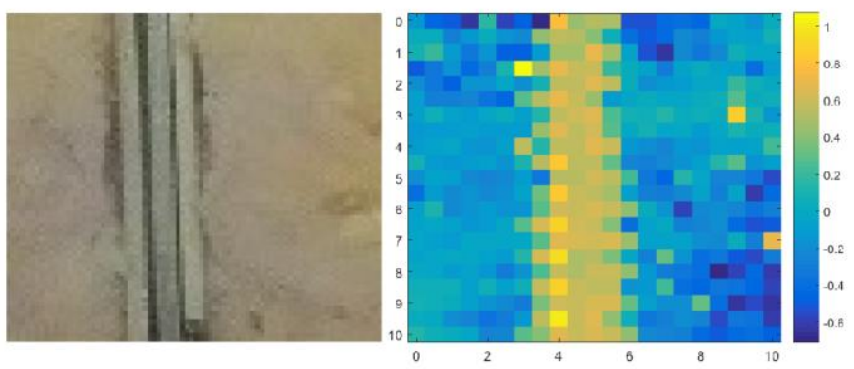

Gambar 14 Hasil citra pada jaringan tumor yang terdapat kawat besi pada permukaannya

Dengan dua hasil citra di atas, maka alat fotoakustik yang telah dibuat sudah dapat digunakan untuk proses analisis terhadap berbagai objek lainnya. Hanya perlu mengatur duty cycle pada proses modulasi lasernya untuk merekam data akustik yang diinginkan. Karena setiap sampel memiliki daya serap yang berbeda terhadap cahaya, untuk material padat maka dibutuhkan duty cycle yang lebih tinggi untuk mendapat puncak akustik dari objek tersebut dan untuk cairan dibutuhkan duty cycle yang lebih rendah agar cairan tidak rusak.

Sistem fotoakustik yang dibuat pada penelitian ini sangat mendukung analisis terhadap jaringan lunak lainnya.Pada pengembangannya, diharapkan alat ini dapat digunakan untuk proses pendeteksi berbagai macam penyakit kanker. Hal ini tentu sangat berguna untuk mengantisaipasi perkembangan kanker lebih ganas dengan pemeriksaan kanker secara dini, sehingga dapat dilakukan suatu upaya pengobatan sebelum jaringan kanker menyebar lebih luas.

\section{KESIMPULAN}

Berdasarkan penelitian yang telah dilakukan, kesimpulan yang dapat diambil adalah :

1. Puncak sinyal akustik pada perekaman dengan kondisi adanya sampel lebih tinggi daripada perekaman hanya dengan laser dan perekaman latar

2. Didapatkan jarak tempuh motor stepper pada satu kali putaran dengan menggunakan actuator ballscrew adalah sejauh $(4,046 \pm 0,005) \mathrm{mm}$.

3. Didapatkan jumlah step yang dibutuhkan untuk proses pemayaran adalah 25 step untuk mendapatkan jarak tempuh $(0,50 \pm 0,05) \mathrm{mm}$.

4. Telah didapatkan suatu citra yang sesuai dengan karakteristik objek hasil dari proses pemayaran.

\section{SARAN}

Berikut adalah saran dari penulis terkait penelitian yang sudah dilakukan :

1. Perekaman puncak sinyal akustik masih dipengaruhi oleh jarak dan bentuk permukaan objek, perlu pengembangan pada sensor (detector) yang lebih baik untuk mendapatkan puncak sinyal akustik tanpa dipengaruhi banyak faktor.

2. Sistem modulasi laser masih menggunakan rangkaian sederhana dengan memberikan variasi waktu on dan off pada laser, diharapkan dapat dibuat sebuah metode modulasi laser yang lebih baik dengan memanfaatkan teknik PWM agar frekuensi yang diberikan pada sistem modulasi laser sesuai dengan frekuensi yang diterima. 


\section{DAFTAR PUSTAKA}

[1]Wang, X., 2004, Functional Photoacoustic Tomography of Animal Brains, Disertasi, A\&M University, Texas.

[2]Montigny, E.D., 2011, Photoacoustic Tomography :Principles and applications, Ecole Polytechnique de Montrea.

[3]Purwanto, J., 2010, Kajian "Teoritis Hamburan Gelombang Elektromagnetik Dalam Tomografi Fotoakustik Untuk Aplikasi Biomedis", Jurusan Fisika Indonesia, No: 42, Vol XIV, Hal 36-51

[4]Harren, F.J.M., 1988, The Photoacoustic Effect, Refined and Applied to Biological Problems, Ph.D. thesis, University of Catholic Nijmegen, The Netherlands.

[5]Hariri, A.,Fatima, A., Mohammadian, N., Bely, N., Nasiriavanaki, M., 2016, "Towards Low Cost Photoacoustic Microskopy System For Evaluation of Skin Health", Proc. of SPIE Vol. 9976 99760X-1-7

[6]Zhang, Y., Cai, X., Choi , S.W., Kim, C., Wang, L.V., Xia, Y., 2010, "Chronic Label-Free Volumatric Photoacoustic Microscopy of Melanoma Cells In Three-Dimensional Porous Scaffolds", Biomaterials Vol.31 8651-8658

[7]Sthorm, E.M., Brendl. E.S.L., Kolios, M.C., 2013, "High Frequency Label-Free Photoacoustic Microscopy of Single Cells", Phoacoustic Vol.1 49-53

[8]Setiawan, A., 2016, Sistem Pencitraan Fotoakustik Sel Terbuka Berbasis Dioda Laser dan Mikrofon Komersial, Fakultas Matematika dan Ilmu Pengetahuan Alam, UGM, Yogyakarta.

[9]S. Setiawan, Rg., Darjat, Setiyono, B., 2011, "Perancangan Modulator Elektro-Optik Transversal Pockels", Transmisi Vol.13 (4) 148-155

[10]Barry L.S., William C.R., Zoltan G.S., 1996, "Intensity-modulated diode laser radar using frequency-modulation/continuous-wave ranging techniques", Opt. Eng. 35(11), 3270-3278

IJEIS Vol. 7, No. 2, October 2017 : $149-160$ 